\title{
ANALYSIS OF THE MAIN CHARACTERISTICS OF THE MODELS OF HIGHLY COMPLEXITY HOSPITAL MANAGEMENT IN THE PROVINCE OF MISIONES
}

\author{
Almúa, Florencia Itatí \\ Faculty of Economics \\ National University of Misiones \\ Miguel Lanús, Misiones, Argentina \\ almua@fce.unam.edu.ar
}

Reception Date: 09/17/2018 - Approval Date:26/01/2019

\section{ABSTRACT}

The processes of State Reform faced in Argentina during the last decades have tended toward the most widespread principles about modern public management techniques.

This work exposes one of the main results presented in the Thesis on the Reforms in the management models of High Complexity Hospitals in the Province of Misiones and its impact on hospital and administrative efficiency indicators, defended by the author in the School of Economic Sciences of the UNaM.

A qualitative approach with descriptive scope is used, where different techniques are used for data collection: unstructured observation, open interviews, review of documents and legal regulations, in order to finalize and compare the management model of the Hospitals of High Complexity of the Province of Misiones.

In the case of hospitals that depend on the Ministry of Health of the province, they identify characteristics of a management model that is closer to the Bureaucratic or Weberian; and, in the case of the Hospital Escuela de Agudos, dependent on the Health Park, the development of different tools and characteristics of the New Public Management.

KEYWORDS: Public Health; Bureaucracy; Public Management.

\section{INTRODUCTION}

The decade of the '90s was characterized by a cycle of structural reforms of the economy. The National Plan for the Modernization of the State, approved by Decree 103 of January 2001, provides for the gradual implementation of a results-based management

\footnotetext{
"Visión de Futuro" Año 16, Volumen N²3 No2, Julio - Diciembre 2019 - Pág. 234 - 251

URL de la Revista: http://visiondefuturo.fce.unam.edu.ar/index.php/visiondefuturo/index

URL del Documento: http://visiondefuturo.fce.unam.edu.ar/index.php/visiondefuturo/issue/view/

ISSN 1668 - 8708 - Versión en Línea

E-mail: revistacientifica@fce.unam.edu.ar
} 
model aimed at "improving daily operational aspects in the functioning of public organizations" (Estévez, A., 2003, p. 7). This Plan proposes three axes for change: i) Change in the Management Model, ii) Structural Modernization Projects and iii) Transparency and Anti-Corruption Policy. With respect to the new Management Model, we try to transform the management by orienting it towards the co-pursuit and achievement of results rather than purely administrative procedures (Estévez, A., 2003).

In particular, the health management model encompasses the political dimension and consists of defining priorities in decisions and values that govern management, such as what kind of information should be provided to the population, what services should be provided directly the State, what and how to buy from the private sector, among others. Thus, for example, the priorities of a hospital of low complexity are not identical to those of another of high complexity. "Defining a management model involves defining the Being, Doing and Being of the Organization" (Tobar, F., 2002, p. 17).

In this framework of major reforms, during the last ten years, the public health sector of the Province of Misiones has also undergone major changes aimed at reducing the shortcomings of public effectors, improving its technical and administrative management and modernizing the health supply offered by the State. On the one hand, the Health Law enacted in 2007, prioritizes the strengthening of structures and actions aimed at the growth of health and establishes, among other concepts, the decentralization of health effectors and I to care by levels, with the Ministry as control agency, auditor and auditor of health policies.

On the other hand, the Law of Creation of the Health Park Dr. Ramón Madariaga sanctioned in 2011, aims to strengthen the level of high complexity. It proposes a new legal figure that combines the public health sector (as a Decentralized Organization, functionally dependent on the Executive Branch through the Ministry of Public Health) with the private sector (the government and the administration is exercised by a Foundation). It proposes an unpublished model in the field of public health in the province, incorporating new public management tools.

Although, it is aimed at achieving a significant change in the public health system, almost ten years after the first reform and six of the second, it is only possible to identify marked differences between the Public Hospitals of High Complexity dependent on the Ministry of Health and the Hospital Escuela de Agudos Dr. Ramón Madariaga, dependent on the Health Park, in terms of operation, infrastructure, technology and resources.

\footnotetext{
"Visión de Futuro" Año 16, Volumen N²3 N², Julio - Diciembre 2019 - Pág. 234 - 251

URL de la Revista: http://visiondefuturo.fce.unam.edu.ar/index.php/visiondefuturo/index

URL del Documento: http://visiondefuturo.fce.unam.edu.ar/index.php/visiondefuturo/issue/view/16

ISSN 1668 - 8708 - Versión en Línea

E-mail: revistacientifica@fce.unam.edu.ar
} 
These differences require the attention of the State, in order to identify the causes that generate them and thus be able to generate tools for the planning of health policies and specific proposals aimed at reducing inequities in the services provided.

In this way, the objective is to characterize and compare the Management Model of High Complexity Public Hospitals of the Province of Misiones, seeking to identify which are the weaknesses and strengths that arise as a result of the proposed reforms, allowing the formulation of proposals tending to optimize the functioning of these institutions.

\section{DEVELOPMENT}

\section{Background}

Silva Bastías \& Galleguillos Peralta (2009) analyze one of the main changes promoted by the Health Reform in Chile, based on the new health authority and management law that began to govern in 2005 in this country. This reform introduces substantial changes in the way of doing health, proposing as challenges of the hospitals to improve the levels of efficiency, the capacity of response to the health problems of the people, reduce the waiting lists, among others.

To analyze the effects of this reform, they take as a reference the situation of the Hospital de Lota, considered of high complexity, as well as its strategic plans, the requirements of the Assistance Network and the requirements of the Health Reform. Based on this analysis, the authors propose a management model that would allow the hospital to respond to the new requirements: a Clinical-Administrative Management Model based on the Responsibility Centers Strategy. The proposed Strategy is based on process management, grouping the sectors that have the same purpose in end, Intermediate or Support Centers.

Bernardes et al., (2012) analyzed through a qualitative study the implementation of the Participative Management Model and the difficulties of the nursing team in the process of changing the management model in a public hospital in Brazil. This model is based on multidisciplinary teams, less layers of hierarchical roles, shared responsibility and a balanced power dynamic, developed in decision processes.

The study was carried out, through a qualitative approach, at a public hospital located in the northeast region of the state of Sao Paulo, Brazil. The main reasons for changes were

\footnotetext{
"Visión de Futuro" Año 16, Volumen N²3 N², Julio - Diciembre 2019 - Pág. 234 - 251

URL de la Revista: http://visiondefuturo.fce.unam.edu.ar/index.php/visiondefuturo/index

URL del Documento: http://visiondefuturo.fce.unam.edu.ar/index.php/visiondefuturo/issue/view/16

ISSN 1668 - 8708 - Versión en Línea

E-mail: revistacientifica@fce.unam.edu.ar
} 
that the hospital had limited spaces with poor administration and needed to improve the orientation of health care towards the needs of the population.

The method used consisted of a series of interviews with thirty-nine workers of the hospital nursing team, related to the modifications identified after the change of the management model and also to changes identified in decision-making, communication and power. Interviews were also held about difficulties faced during and after the implementation process.

They conclude that the implementation of the Participatory Management Model allowed internal improvements in the hospital institution and studied, with positive repercussions for the provision of care to patients, mainly during the initial years of change. However, the implementation of this model may be impaired when there is no commitment on the part of the team to implement decentralized structures, team participation, shared responsibility and communication with stakeholder groups. Thus, although the formally adopted management model was Participatory Management, the Traditional Management Model was eliminated due to the lack of definition of functions and responsibilities towards the professionals and managers of the organization.

Vilchis (2005) analyzes the presence of different aspects of the New Public Management (NPM) in the strategies applied by the governments of eighteen Mexican states in their public administrations. It examines in detail the official documents of the country, using a methodology to construct indicators that allow to measure the intensity with which the states studied executed NPM actions. Its objective is to demonstrate that the NPM is present in the different actions undertaken by the state governments of Mexico.

The author maintains as a hypothesis that the federal entities of the Mexican Republic are implementing various techniques and strategies of the new public management, without having a systematic method to carry them out.

It concludes that in general, in all the governments, independently of the party that governs, there are normative documents with actions related to the new public management and that, in addition, the types of variables that exert influence to adopt the new public management in the states: political variables, economic variables, social variables and, probably, internal administration variables of the government itself.

Rezzoagli (2015) analyzes the creation of entities with management models oriented to results in the public sector of the Provincial Administration of Santa Fe, as a consequence of the influence of the postulates of the new public management.

\footnotetext{
"Visión de Futuro" Año 16, Volumen N²3 N², Julio - Diciembre 2019 - Pág. 234 - 251

URL de la Revista: http://visiondefuturo.fce.unam.edu.ar/index.php/visiondefuturo/index

URL del Documento: http://visiondefuturo.fce.unam.edu.ar/index.php/visiondefuturo/issue/view/16

ISSN 1668 - 8708 - Versión en Línea

E-mail: revistacientifica@fce.unam.edu.ar
} 
Through an analysis of the legal-public order, it indicates that in this province there is a proliferation of instrumental entities created by the provincial Administration, such as instrumental entities in a legal-public form subject to Public Law, instrumental entities in legal-public form subject to Private Law, and entities organized in a legal-private manner. Thus, analyzes the operation of companies that are part of instrumental public sector of Santa Fe, on issues such as contracting, external control of public spending and the mechanism for accountability, concluding that the transition from a bureaucratic managment to post-bureaucratic management in the province of Santa Fe, has not been accompanied by the necessary expansion towards an external control of management and evaluation of results.

Although it recognizes that the flexibility and management autonomy proposed by the NPM can favor the attainment of previously established objectives, taking into account efficiency, efficiency and economy parameters, the author also concludes that if certain guarantees of Public Law are not adopted nor the adequacy of the state controls to the management by results, the implementation of postulates of the NPM allows discretion that can increase the risks of inefficiency and favor corruption practices.

Zuleta (2003) carries out a work of explorative nature, where he establishes some characteristics about the New Public Management and the results of its implementation in the Public Administration of Córdoba. For this, it organizes its work in three sections, presenting first a series of guiding principles and concepts of the NPM; then it analyzes how such characteristics have been implemented in the Public Administration of Córdoba and the characteristics that it has; and, finally, it establishes conclusions and raises some hypotheses referred to the weakness of the managerial model in the Public Administration of this province.

Through informal interviews with the managers of the Central Level of the Ministry of Health, the author finds some characteristics that make reference to the new management model: although the characteristic hierarchical dependency system remains constant, a transversality is also manifested, which links with other administrative units outside or within the scope of the Ministry of Health; it has not been possible to determine the decentralization of responsibilities characteristic of the NPM; the power and responsibility (accountability) necessary to solve problems do not appear as resolutive instruments in this new managerial model; The orientation towards clients seems not to be

\footnotetext{
"Visión de Futuro" Año 16, Volumen No 23 N², Julio - Diciembre 2019 - Pág. 234 - 251

URL de la Revista: http://visiondefuturo.fce.unam.edu.ar/index.php/visiondefuturo/index

URL del Documento: http://visiondefuturo.fce.unam.edu.ar/index.php/visiondefuturo/issue/view/16

ISSN 1668 - 8708 - Versión en Línea

E-mail: revistacientifica@fce.unam.edu.ar
} 
important for the actors and the orientation towards results presents a weak tendency as a management tool for the employees.

The author concludes that although the results of the new management model in the Public Administration of Córdoba have not been satisfactory, it must be under constant review. It formulates the hypothesis of weakness of the managerial model with respect to the old bureaucratic - administrative (or Weberian) model, sustained mainly by the persistence of strong features of the old model that maintain the problem of state inefficiency.

\section{State Management Reform}

Since the beginning of the 1980s a strong current of state reform has been felt in the public administrations of Western countries (Estévez, A., 2001, p.1).

The 90s saw Latin America inspired by the models and management techniques applied in the $80 \mathrm{~s}$ in developed countries, which led to reforms that put a strong emphasis on the need to change the traditional bureaucratic model in force in Public Administrations towards a model of Public Management type.

The institutionalization of a new public management "implies abandoning both the traditional bureaucratic conception, of a clientelistic type...like the unconditional adherence to the rational-legal conception of the Weberian stamp" (Estévez \& Blutman, 2005, p. 5).

Hintze (2003), for his part, points out that the state reform of the last decades of the twentieth century produced an unprecedented consensus about the benefits of managing for results. In the field of public management, the most common words were results and decentralization, which indicated greater decision autonomy for managers to achieve better results. On the other hand, the word process, instead of referring to organization and efficiency, was accentuated as a synonym of bureaucratization, representing a rigid and indifferent routine to the true needs of the users.

According to Estévez \& Blutman (2005), in Argentina, although the process of state reform was one of the deepest in Latin America, carried out during the presidency of Dr. Carlos Menem (1989-1999), it is important It should be noted that the bureaucraticlegal model never reached a level of termination similar to that of the developed countries, since the principles of the Weberian paradigm were not even consolidated.

These authors define the stages of State Reform in Argentina as follows:

\footnotetext{
"Visión de Futuro" Año 16, Volumen No 23 N², Julio - Diciembre 2019 - Pág. 234 - 251

URL de la Revista: http://visiondefuturo.fce.unam.edu.ar/index.php/visiondefuturo/index

URL del Documento: http://visiondefuturo.fce.unam.edu.ar/index.php/visiondefuturo/issue/view/16

ISSN 1668 - 8708 - Versión en Línea

E-mail: revistacientifica@fce.unam.edu.ar
} 
The first stage of State Reform in Argentina began towards the end of 1989 and extended until 1996. Here, drastic measures of privatization and reductions of personnel were undertaken at the federal level.

In 1996, the Law and No. 24,629 of the Second State Reform were approved. This enabled the reduction and elimination of Secretariats and Sub-Secretariats, in order to reduce again the fiscal deficit in the face of the international financial crisis known as the Tequila effect. In addition, strategic plans for some decentralized agencies of the Public Administration were implemented for the first time in Argentina.

In December 1999, work began on the development of the so-called State Modernization Plan, approved by presidential decree in January 2001. This plan sought to incorporate some of the principles of performance management or managerialist government orientation. The Plan proposes three axes for change: i) Change in the management model, ii) Structural modernization projects, and iii) Transparency and anticorruption policy. Regarding the new Management Model, the Plan tried to transform the management from the unfailing application of administrative procedures towards the attainment and achievement of the results. This was aimed at implementing two types of transformations: institutional and horizontal. With respect to the former, the modernization project sought to establish results-based management (RBM) in some key agencies, trying to implement the accountability requirement and the adaptation of the Program Budget to Strategic Planning.

Beyond the excessive size of the state apparatus, this Plan put the accent on its deformity, foreseeing the gradual instrumentation of a management model by results and the signature in some agencies of the commitment letter with the citizen (Estévez, A., 2003, p. 7).

This modernization process aims to build a more effective and efficient State. In this sense, modernizing the State means that management, instead of relying exclusively on administrative-bureaucratic procedures, is oriented towards the search for results by accounting for them.

\section{Types of Reform Programs}

In general, three main types of reform programs can be distinguished: Weberian, accountability or managerial.

\footnotetext{
"Visión de Futuro" Año 16, Volumen N²3 N², Julio - Diciembre 2019 - Pág. 234 - 251

URL de la Revista: http://visiondefuturo.fce.unam.edu.ar/index.php/visiondefuturo/index

URL del Documento: http://visiondefuturo.fce.unam.edu.ar/index.php/visiondefuturo/issue/view/16

ISSN 1668 - 8708 - Versión en Línea

E-mail: revistacientifica@fce.unam.edu.ar
} 
The Weberian reforms "try to suppress clientelism and patrimonialism through the construction of a professional bureaucratic career system, granting bureaucratic autonomy with respect to politics" (Estévez \& Blutman, 2005, p. fifteen). Some of its negative consequences are rigidity, lack of accountability and inefficiency.

With respect to the accountability reforms, they seek to "increase the political control of the bureaucracy, through the instrumentation of accountability mechanisms especially through the electoral system and the control of the congress." (Estévez \& Blutman, 2005, p.15).

Finally, managerial reforms "try to transform the operation of the public apparatus to eliminate what they consider unnecessary paperwork, rigidity, particularism and inefficiency in the behavior of the administration" (Estévez \& Blutman, 2005, p. 16). The characteristic tools of this model are: management contracts, decentralization and the end of the stability of public officials.

Now, in this path of reforms, an unsystematic implementation has been generated where two unfinished models coexist: the old Weberian paradigm, which "seeks efficiency but ends up being inefficient" and the New Public Management, "with isolated and loaded measures of vicissitudes that preclude its full implementation "(Estévez \& Blutman, 2005 , p. 17-18). In this context, and due to the lack of completion of both ideas, these authors propose an intermediate path, through a bureaucracy but with a greater orientation towards results.

\section{Traditional Bureaucracy}

According to Estévez \& Blutman (2005) the classic characteristics of a legalistic bureaucracy are: 1) Specialization of tasks: division of labor, distribution of obligations or trades and roles among a certain number of positions; 2) the use of regulations or legality, as an element in the regulation of the decision process.

For his part Weber (1972), points out as some of the main characteristics of the bureaucracy the following: a) organization through laws or administrative orders, with normal activities conceived as official duties, whose compliance is ensured by a system of standards; b) the Principle of Hierarchy of positions, where superior officials control the inferiors; c) the position of the official is usually for life.

For Ramió Matas (2001) the concept of bureaucracy is associated with a hierarchical organization where each unit has clearly defined responsibilities, and its actions are regulated by rules andscritches and vertical control mechanisms.

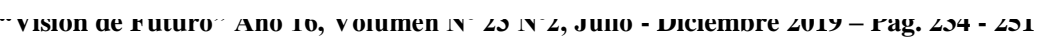

URL de la Revista: http://visiondefuturo.fce.unam.edu.ar/index.php/visiondefuturo/index

URL del Documento: http://visiondefuturo.fce.unam.edu.ar/index.php/visiondefuturo/issue/view/16

ISSN 1668 - 8708 - Versión en Línea

E-mail: revistacientifica@fce.unam.edu.ar 
As for the reasons for the progress of the bureaucracy with respect to any other form of organization, Weber (1972) emphasizes the purely technical superiority of this type of organization and the principle of specifying the administrative functions according to strictly objective regulations.

Thus, once it has been fully established, the bureaucracy constitutes one of the most difficult social structures to destroy. The governed can not dispense with the bureaucratic apparatus of authority, or replace it, when it already exists, since this bureaucracy is based on a "specialized preparation, a functional division of labor, and a constellation of methodically integrated attitudes" (Weber, M., 197 2, p.85).

Within its classification of configurations or pure models of organizations Mintzberg (1991) identifies two types of Bureaucracy:

1. The Mechanical Bureaucracy: some of the main characteristics of this type of structure are: division of work, routine operational tasks, strictly formal communication, standardization of processes, procedures formalized in the operative nucleus, proliferation of rules, regulations and formalized communication throughout the organization.

It constitutes the structure closest to that described by Max Weber "with responsibilities, qualifications, channels of communication and standardized work rules, as well as a hierarchy of clearly defined authority" (Mintzberg, H., 1991, p. 139). The power of decision in this type of organizations is quite centralized, with high levels of control, where a closed, tightly controlled atmosphere develops. As the standardization of work processes handles most of the coordination, direct supervision by contact officers is limited. The formal power resides in the top, being the hierarchy and the chain of authority fundamental concepts.

2. The Professional Bureaucracy: it is a highly decentralized structure, which concentrates a large amount of power at the base of the structure, with the operating core professionals. The main difference with the mechanical bureaucracy lies in the source of its standardizations. While the latter structure generates its own norms, in the professional bureaucracy "they originate outside their own structure, in the self-governed associations to which their operators unite with their colleagues in other professional bureaucracies" (Mintzberg, H., 1991, p. 161), establishing universal norms taught by the Universities and used by all the bureaucracies of the profession.

\footnotetext{
"Visión de Futuro" Año 16, Volumen No 23 N², Julio - Diciembre 2019 - Pág. 234 - 251

URL de la Revista: http://visiondefuturo.fce.unam.edu.ar/index.php/visiondefuturo/index

URL del Documento: http://visiondefuturo.fce.unam.edu.ar/index.php/visiondefuturo/issue/view/16

ISSN 1668 - 8708 - Versión en Línea

E-mail: revistacientifica@fce.unam.edu.ar
} 
This is the case of Universities and Hospitals, where the professional has autonomy and responsibility for their actions. The main coordinating mechanism results from the standardization of skills, since complex work processes make standardization difficult. It also reacts slowly to changes in the context.

\section{Theories of New Public Management (NPM)}

The New Public Management (NMP) or New Public Management (NGP) is known to be inspired by the practices of the private sector: customer orientation, insistence on the entrepreneurial aspect of the functionary or public, management oriented towards results, etc.

Following Estevez (2001) the NMP would be the new ethos or organizational culture, which aims to form a common cultural behavior in the members of the public administration, replacing the traditional culture of the public administration. It was used as an instrument of change in the administrations of developed countries and its advent coincides with the assumption of Margaret Thatcher as Prime Minister of Great Britain in 1979.

This decision to reform the British public administration took place in a favorable political, cultural, social and economic context, which increased the loss of confidence of the public of developed countries in the capacities of their governments to offer them quality public services or an effective and efficient way. This loss of confidence that had its climax in the 90s, resulted in a profound questioning of the role of the State (Estévez, A., 2001).

Other determining factors in this reform were related to the growth of indebtedness and public deficit in the 70s, globalization (due to its impact outside borders) and new technologies. This leads States to reconsider their internal management, review the modes of provision of public services and reexamine the process of preparing or implementing policies, seeking to minimize costs and efficiency.

Considering that the Management for Results (MFR) model is inspired by the managerial vision of public management, Estévez (2003) highlights it as a management tool for organizations that: 1) Structure management around the results-products process resources;2) Decentralizes decision making and makes the use of resources more flexible; 3) It relates the strategic planning, the budget process, the monitoring of management and the rendering of accounts by results; and 4) It is characterized by the predominance of creative actions and quality routines.

Implementing the MFR involves developing systematic processes of strategic planning, transforming the budget into a real management tool that allows measuring the

“Visión de Futuro" Año 16, Volumen N²3 N², Julio - Diciembre 2019 - Pág. 234 - 251

URL de la Revista: http://visiondefuturo.fce.unam.edu.ar/index.php/visiondefuturo/index

URL del Documento: http://visiondefuturo.fce.unam.edu.ar/index.php/visiondefuturo/issue/view/16

ISSN 1668 - 8708 - Versión en Línea

E-mail: revistacientifica@fce.unam.edu.ar 
results achieved, redefining the processes in order to improve the internal management of the agencies and the implementation of monitoring systems for the management and accountability (Estévez, A., 2003).

Management by results incorporates strategic planning in the determination of the mission, strategy and objectives of the institution. It also includes the design of a system of positive and negative selective incentives for the performance of its human resources and organizes a management control system validated through quali-quantitative indicators (Essayag, S., 2000).

Zuleta (in Shepherd 1999) synthesizes the New Public Management as a model where decision-making is delegated, thus reducing the hierarchical load and granting greater decision-making power to managers; and on the other hand, a brand with an emphasis on guiding the process towards results, customers and the market.

\section{Differences between the Traditional Bureaucracy and the NPM}

Table №1 presented by Estévez (in Charih and Daniels, 1997, Aucoin, 1995, and Mathiasen, 1996) summarizes the main elements that distinguish the NPM from Traditional Public Management:

Table $\mathrm{N}^{\circ}$ 1. Comparison between the NPM and the Traditional Public Management

\begin{tabular}{|c|c|c|}
\hline Component & NPM & $\begin{array}{c}\text { Traditional Public } \\
\text { Management }\end{array}$ \\
\hline Focus & Customers. & Citizens and communities. \\
\hline Major resources or tools & Management. & $\begin{array}{l}\text { Implementation of public } \\
\text { policies. }\end{array}$ \\
\hline $\begin{array}{l}\text { Characteristics of public } \\
\text { officials }\end{array}$ & $\begin{array}{l}\text { Entrepreneurs, the action is } \\
\text { valued. }\end{array}$ & $\begin{array}{l}\text { Analyst, thought and } \\
\text { conceptualization are valued }\end{array}$ \\
\hline Values & $\begin{array}{l}\text { Entrepreneurial spirit, freedom } \\
\text { of action for managers, } \\
\text { flexibility, } \\
\text { enthusiasm, propensity to risk, } \\
\text { etc. }\end{array}$ & $\begin{array}{l}\text { Prudence, stability in the } \\
\text { position, seniority, ethics, } \\
\text { probity, justice, transparency, } \\
\text { etc. }\end{array}$ \\
\hline Vocabulary & 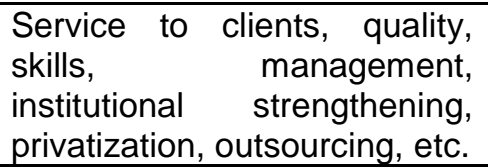 & $\begin{array}{l}\text { Public or general interest, } \\
\text { democracy, social equity, due } \\
\text { process, regulations, etc. }\end{array}$ \\
\hline Organizational culture & $\begin{array}{l}\text { Characteristics of the private } \\
\text { sector, innovation, private or } \\
\text { commercial management, } \\
\text { responsibility for results, } \\
\text { increase in the dichotomy } \\
\text { between administration and } \\
\text { politics. }\end{array}$ & $\begin{array}{l}\text { Bureaucratic and hierarchical, } \\
\text { accent on functions, stability, } \\
\text { responsibility for processes, } \\
\text { dichotomy between } \\
\text { politics and administration is } \\
\text { seen as a continuum. }\end{array}$ \\
\hline
\end{tabular}

\footnotetext{
“Visión de Futuro" Año 16, Volumen N²3 N², Julio - Diciembre 2019 - Pág. 234 - 251

URL de la Revista: http://visiondefuturo.fce.unam.edu.ar/index.php/visiondefuturo/index

URL del Documento: http://visiondefuturo.fce.unam.edu.ar/index.php/visiondefuturo/issue/view/16

ISSN 1668 - 8708 - Versión en Línea

E-mail: revistacientifica@fce.unam.edu.ar
} 


\begin{tabular}{|l|l|l|}
\hline Structures & $\begin{array}{l}\text { The Civil Service is seen as a } \\
\text { sum of simple and small }\end{array}$ & $\begin{array}{l}\text { The Civil Service is an } \\
\text { institution, endowed with large } \\
\text { organizational units. }\end{array}$ \\
departments and \\
The structures are of the & $\begin{array}{l}\text { divisions. The structures will } \\
\text { horizontal type. The market } \\
\text { be pyramidal and hierarchical. } \\
\text { mechanism is valued that } \\
\text { favor the decentralization of } \\
\text { authority. }\end{array}$ & $\begin{array}{l}\text { The authority will be } \\
\text { centralized at the top. }\end{array}$ \\
\hline
\end{tabular}

Source: Estévez 2001: 7 (in Charih \& Daniels, 1997, Aucoin, 1995, and Mathiasen, 1996)

Following Estévez (2001), referring to the dilemma products or processes, the NPM is directed towards results, while the traditional bureaucracy is centered around the processes. In the latter, quality control is oriented to strict compliance with regulations and regulatory procedures, without giving great attention to final products.

Another aspect to be considered is the change in the focus of attention that, on the one hand, for the Bureaucracy, centers on the citizen; and in the NPM it becomes the client. A political category is changed to another economic category.

Essayag (2000) points out that at the administrative-governmental level, it means moving from a system of centralized intergovernmental relations to a decentralized one; from a highly discretionary legal and administrative system to an effective Rule of Law; from a rigid and autocratic Public Administration to a progressively flexible one.

\section{Organizational Culture according to the method of Management}

Organizational culture can be defined as the set of norms, beliefs, values, customs, rituals, languages, artifacts and basic presumptions that exist and govern an organization.

Regarding the types of organizational culture, Góngora \& Reija (2013) and Estévez \& Blutman (2005) coincide in the identification of five types: Paternalistic, Apathetic, Anomic, Demanding and Integrative. This typification arises from the crossing of two dimensions: on the one hand, orientation towards people and, on the other, towards results.

The Paternalist culture "prioritizes the care of interpersonal relationships over the orientation to results, objectives and goals" (Estevez \& Blutman, 2005, p. 24).

On the contrary, both in the A ptica culture and in the Anomic culture there is a low orientation to the people as well as to the results.

Demanding culture, on the other hand, is based on setting objectives and demanding compliance, encouraging internal competition and insensitivity to the needs of others. Efficiency and individual contributions are prioritized, judged and rewarded or punished for what is produced, placing special emphasis on results.

\footnotetext{
"Visión de Futuro" Año 16, Volumen No 23 N², Julio - Diciembre 2019 - Pág. 234 - 251

URL de la Revista: http://visiondefuturo.fce.unam.edu.ar/index.php/visiondefuturo/index

URL del Documento: http://visiondefuturo.fce.unam.edu.ar/index.php/visiondefuturo/issue/view/16

ISSN 1668 - 8708 - Versión en Línea

E-mail: revistacientifica@fce.unam.edu.ar
} 
Finally, the Integrative culture combines levels of orientation with people and high levels of orientation towards results, which implies "strategic direction, vision, commitment, consistency, teamwork, adaptation to changes, fluid internal communication and a high concern for individual and group performance". (Estévez \& Blutman, 2005, p. 26).

The paternalistic, apathetic and anomic cultural types are considered traditional, where the apathetic represents the Weberian model. Meanwhile, the Integrative and the Demanding, have more modern characteristics, combined with the New Public Management.

\section{Structure and Decentralization in decision making}

Mintzberg (1991) analyzes the question of centralization and decentralization exclusively in terms of power over decisions made in the organization. This author points out that when all the power of decision-making rests on a single point in the organization, that is, in the hands of a person, the structure is considered centralized; to the extent that power is dispersed among many people, the structure is decentralized.

In this sense, he distinguishes three common uses of the term decentralization: 1) when, through the chain of command, power is dispersed from the central authority downwards (vertical decentralization); 2) When the power of decision remains with the line managers in the formal authority system or with people outside the line structure, such as analysts, support specialists and operators (horizontal decentralization); 3) Finally, the term decentralization is also used to refer to the physical dispersion of services, but in this case it is not related to decision making, so the author refers to the concepts of concentrate and dispose when what is described is physical location.

In turn, the author classifies five types of horizontal and vertical decentralization:

- Vertical and horizontal centralization: the power of decision is concentrated in the hands of a single individual in the hierarchy of the hierarchical line. It retains both formal and informal power, deciding on all important issues and coordinating execution through direct supervision.

- Limited horizontal decentralization: here is the bureaucratic organization with unskilled tasks, which coordinates through the standardization of work processes. The latter diminishes the importance of direct supervision as a coordination and control mechanism, but it also reduces the power of middle-line managers, particularly at lower levels.

\footnotetext{
"Visión de Futuro" Año 16, Volumen No 23 N², Julio - Diciembre 2019 - Pág. 234 - 251

URL de la Revista: http://visiondefuturo.fce.unam.edu.ar/index.php/visiondefuturo/index

URL del Documento: http://visiondefuturo.fce.unam.edu.ar/index.php/visiondefuturo/issue/view/16

ISSN 1668 - 8708 - Versión en Línea

E-mail: revistacientifica@fce.unam.edu.ar
} 
- Vertical parallel decentralization: occurs in organizations composed of market units or divisions where the decision-making power is focused on their respective managers, and does not need to be delegated further down the chain of authority. Even so, the strategic summit retains the final formal power over the divisions, coordinating and regulating its behavior through performance control systems. The leader focuses mainly on the middle line and to a lesser extent on the strategic summit and on the top of the technostructure. It refers to the dispersion of power for many kinds of decisions to the same place. Mintzberg (1991) points out that this type of The structure is also known as divisionalized in the corporate sector. In this framework (of the market-based units), the author points out that divisionalization is a limited form of vertical decentralization, since it only implies giving considerable decision-making power to a few people, who are the managers of the market units in the middle line.

- Vertical and horizontal selective decentralization: In this case the power over different types of decision falls on different parts of the organization with different levels of hierarchy. Its application leaves important interdependencies to be reconciled, which originates the need for coordination and control, which is fundamentally developed through mutual adjustment. Regarding horizontal decentralization, selective use is made of the staff experts, according to what techniques should be the decisions they must make. The power expands in several places, concentrating on the support staff to a large part of the experts of the organization.

- Vertical and horizontal decentralization: the power of decision is concentrated mostly in the operational level, lower part of the hierarchy. Its members are professionals and coordinate their work through the standardization of skills.

Thus, in each structure configuration typified by Mintzberg, a different coordination mechanism dominates, a key part of the organization is also different and, with it, a type of decentralization.

\section{Qualitative Methodology}

Methodology

A qualitative approach with descriptive scope is used, where different techniques are used for data collection: unstructured observation, open interviews, review of documents and legal regulations, in order to analyze and compare the management model of Alta Hospitals. Complexity of the Province of Misiones identifying the main focal points.

\footnotetext{
"Visión de Futuro" Año 16, Volumen N²3 N², Julio - Diciembre 2019 - Pág. 234 - 251

URL de la Revista: http://visiondefuturo.fce.unam.edu.ar/index.php/visiondefuturo/index

URL del Documento: http://visiondefuturo.fce.unam.edu.ar/index.php/visiondefuturo/issue/view/16

ISSN 1668 - 8708 - Versión en Línea

E-mail: revistacientifica@fce.unam.edu.ar
} 
The Study Universe: High Complexity Public Hospitals of the Province of Misiones: Samic Iguazú Hospital Dra. Marta Shwartz, Samic Eldorado Hospital, Samic Oberá Hospital, Dr. Fernando Barreyro Pediatric Hospital, Neonatal Maternal Hospital and the Hospital Escuela de Agudos Dr. Ramón Madariaga.

The Sample: Hospitals of High Complicity of adults: Hospital Samic Eldorado, Hospital Samic Oberá and Hospital Escuela de Agudos Dr. Ramón Madariaga.

\section{Administrative decentralization and efficiency in hospitals of high complexity}

Both the Health Law of the Province of Misiones and the one created by the Dr. Ramón Madariaga Health Park coincide in the commitment to an efficient management model with administrative decentralization for the specific case of third-level hospitals.

By virtue of this, interviews were held with different key informants of the hospitals under the Ministry of Health, Samic Eldorado and Samic Oberá, and the Hospital Escuela de Agudos Dr. Ramón Madariaga. The purpose of these was to inquire about the functioning of the effectors, mainly around two processes: decision making and purchasing management.

Regarding decision-making, the open interviews basically consisted of being able to determine the degree of decentralization for decision-making between the hospital and the Ministry.

In the same line, we proceeded to conduct open interviews with key informants of the Hospital Escuela de Agudos, in order to know the process through which decisions are made in this new structure driven by the reform that created the Parque de la Health.

To know about the process of purchasing management for a usual procedure of hospitals dependent on the Ministry of Health, where the decisions of the central level are involved, open interviews were carried out with relevant administrative personnel of the responsible management.

In the case of the Hospital Escuela de Agudos, the contracting system is distinctive, while the Law that creates the Health Park (X VII No. 70 ) in its article 5 empowers the Executive Power to fix the contracting regime of the Park and apply additionally the provisions of laws VII - $\mathrm{N}^{\circ} 11$ (Formerly Law 2303 of Accounting) and X $-\mathrm{N}^{\circ} 4$ (Formerly Law 83 of Public Works). Of this man was, although the article $N^{\circ} 8$ of Decree 83/12, which regulates the Law XVII $N^{\circ} 70$, establishes as a general rule to the Public Bid, also enables

\footnotetext{
"Visión de Futuro" Año 16, Volumen N²3 N², Julio - Diciembre 2019 - Pág. 234 - 251

URL de la Revista: http://visiondefuturo.fce.unam.edu.ar/index.php/visiondefuturo/index

URL del Documento: http://visiondefuturo.fce.unam.edu.ar/index.php/visiondefuturo/issue/view/16

ISSN 1668 - 8708 - Versión en Línea

E-mail: revistacientifica@fce.unam.edu.ar
} 
recourse to the procurement of inputs, goods or services needed previous price contest and / or antecedents. To do this, invitations must be sent to at least three suppliers, whose offers will be analyzed by a Purchasing Committee of the Foundation and will advise the Administration Office for the processing of the contract.

From the interviews carried out, Table $\mathrm{N}^{\circ} 2$ could be drawn up. It can be observed how, from the determination of the characteristics of each hospital, it is possible to approach the hospitals dependent on the Ministry of Health to a traditional bureaucratic management model. or Weberiano and the Hospital Escuela de Agudos to a management model that is closer to the New Public Management.

Table $\mathbf{N}^{\circ}$ 2. Main differences and similarities between High Complexity Hospitals dependents of the Ministry of Health and the Health Park of the Province of Misiones

\begin{tabular}{|c|c|c|}
\hline & $\begin{array}{c}\text { Samic Eldorado and Samic } \\
\text { Oberá Hospitals }\end{array}$ & $\begin{array}{c}\text { Hospital Escuela de Agudos } \\
\text { Dr. Ramón Madariaga }\end{array}$ \\
\hline Bet of the Reformation & $\begin{array}{l}\text { Administrative } \\
\text { decentralization. }\end{array}$ & $\begin{array}{l}\text { Administrative decentralization a } \\
\text { nd efficiency. }\end{array}$ \\
\hline $\begin{array}{l}\text { Maximum authority in } \\
\text { decision making }\end{array}$ & Governor - Minister. & $\begin{array}{l}\text { President of the Foundation that } \\
\text { administers and governs the } \\
\text { Health Park. }\end{array}$ \\
\hline $\begin{array}{l}\text { Administrative } \\
\text { decentralization }\end{array}$ & Half. & High. \\
\hline contracting & $\begin{array}{l}\text { Law VII - N } 11 \text { (Before Law } \\
2303 \text { of Accounting). }\end{array}$ & $\begin{array}{l}\text { Supplementary use of Law VII } \\
\mathrm{N}^{\circ} 11 \text {. Price competition. }\end{array}$ \\
\hline $\begin{array}{l}\text { Estimated average time in } \\
\text { shopping processes }\end{array}$ & $\begin{array}{l}\text { Estimated: from } 8 \text { months to } 1 \\
\text { year or more (according to the } \\
\text { authorization of the CCGP) }\end{array}$ & Estimated: 30 days \\
\hline $\begin{array}{l}\text { Leg instrument to } \\
\text { approve the procedures }\end{array}$ & $\begin{array}{l}\text { Ministerial Resolution or } \\
\text { Decree of the Executive } \\
\text { Power. }\end{array}$ & $\begin{array}{l}\text { Provision of the president of the } \\
\text { Foundation that administers and } \\
\text { governs the Health Park. }\end{array}$ \\
\hline Orientation & Processes. & Results. \\
\hline Main resources or tools & $\begin{array}{l}\text { Follow } \\
\text { public health policies delineate } \\
d \text { by the Executive Power and } \\
\text { the Ministry of Health }\end{array}$ & Management. \\
\hline Organizational culture & $\begin{array}{l}\text { Bureaucratic and } \\
\text { hierarchical. Health Career } \\
\text { Law Stability. Permanent } \\
\text { plant. }\end{array}$ & $\begin{array}{l}\text { Private type management. I } \\
\text { accepts to liquidate its additiona } \\
\text { personnel for production, greater } \\
\text { benefit and / or greater } \\
\text { responsibility. He only hires } \\
\text { temporary staff. }\end{array}$ \\
\hline
\end{tabular}

\footnotetext{
"Visión de Futuro" Año 16, Volumen N²3 N², Julio - Diciembre 2019 - Pág. 234 - 251

URL de la Revista: http://visiondefuturo.fce.unam.edu.ar/index.php/visiondefuturo/index

URL del Documento: http://visiondefuturo.fce.unam.edu.ar/index.php/visiondefuturo/issue/view/16

ISSN 1668 - 8708 - Versión en Línea

E-mail: revistacientifica@fce.unam.edu.ar
} 


\begin{tabular}{|l|l|l|}
\hline $\begin{array}{l}\text { Structure according to } \\
\text { Mintzberg }\end{array}$ & $\begin{array}{l}\text { Professional Bureaucracy (in } \\
\text { hospitals) and Mechanics (in } \\
\text { the Ministry). }\end{array}$ & Simple structure. \\
\hline $\begin{array}{l}\text { Decentralization accordin } \\
\text { g to Mintzberg }\end{array}$ & $\begin{array}{l}\text { Horizontal horizontal } \\
\text { decentralization. }\end{array}$ & Vertical centralization. \\
\hline $\begin{array}{l}\text { Organizational Culture } \\
\text { according to Estévez and } \\
\text { Blutman }\end{array}$ & Apathetic. & Integrative. \\
\hline MANAGEMENT MODEL & $\begin{array}{l}\text { BUROCRÁTICO } \\
\text { WEBERIANO }\end{array}$ & NEW PUBLIC MANAGEMENT \\
\hline
\end{tabular}

Source: Prepared by the authors on the basis of results of open interviews, Law XVII No. 70, Law VII - № 11 (formerly Law 2303 of Accounting) and Decree 83/12 of the Province of Misiones

\section{CONCLUSION}

The path of reforms proposed by the government of the Province of Misiones during the last two years in the field of Public Health has promoted two divergent management models among the High Complexity Hospitals that make up its health offer.

In the effectors that depend on the Ministry of Health, characteristics close to a bureaucratic or Weberian management model were identified; meanwhile, the Hospital Escuela de Agudos, dependent on the Health Park, has developed, from its beginnings to date, different tools of the New Public Management.

The qualitative analysis shows signs that grant considerable administrative advantages to the Hospital Escuela de Agudos over Hospitals that depend on the Ministry, in terms of administrative deadlines and procedures.

On the other hand, the excessive orientation towards processes and the high centralization in decision-making generate delays and uncertainty from the beginning of any procedure in the functioning of the effectors dependent on the Ministry of Health.

The provincial government should pay special attention to the effects generated by these types of reforms, especially when they deepen the differences between the effectors, resulting in the provision of inequitable public health services.

\footnotetext{
"Visión de Futuro" Año 16, Volumen No 23 N², Julio - Diciembre 2019 - Pág. 234 - 251

URL de la Revista: http://visiondefuturo.fce.unam.edu.ar/index.php/visiondefuturo/index

URL del Documento: http://visiondefuturo.fce.unam.edu.ar/index.php/visiondefuturo/issue/view/16

ISSN 1668 - 8708 - Versión en Línea

E-mail: revistacientifica@fce.unam.edu.ar
} 


\section{REFERENCES}

Please refer to articles in Spanish Bibliography.

\section{BIBLIOGRAPHCIAL ABSTRACT}

Please refer to articles Spanish Biographical abstract. 